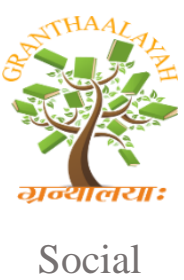

$$
\begin{gathered}
\text { INTERNATIONAL JOURNAL OF RESEARCH - } \\
\text { GRANTHAALAYAH } \\
\text { A knowledge Repository }
\end{gathered}
$$

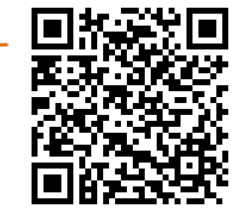

\title{
PROBLEM OF EDUCATION IN KARBI ANGLONG DISTRICT
}

\author{
Miss Sobita Tokbipi ${ }^{* 1}$ \\ ${ }^{* 1}$ Department of Education, Howraghat College, Assam, India
}

\begin{abstract}
The Karbi Anglong district of Assam is very rich in natural resources. This district has very low infrastructure facilities as well as low percentage of literacy. Our government both at the centre and in the state have tried to improve and expand education since the attainment of freedom. In Karbi Anglong district, many children leave the schools even before completing the primary education.

The present education system in Karbi Anglong district is not satisfactory with respect to competitive world. The problem of education is somewhat different from other district of Assam. The rate of literacy is still very low in this district because there are many hindrance in the education system. Another very serious problem of education in Karbi Anglong district is the differences in educational attainment between male and female. This district is facing from big educational problem even though our government has taken many steps and measurement. Therefore, our state government should take proper action to some extent to be at par with the modern competitive world. The present problem of education should be identified and proper step should be taken to solve this problem.
\end{abstract}

Keywords: Education; Literacy; Government; Infrastructure.

Cite This Article: Miss Sobita Tokbipi. (2017). "PROBLEM OF EDUCATION IN KARBI ANGLONG DISTRICT." International Journal of Research - Granthaalayah, 5(9), 91-94. https://doi.org/10.29121/granthaalayah.v5.19.2017.2204.

\section{Introduction}

The Hill district Karbi Anglong of Assam is under the sixth schedule area of Indian constitution resided by multi-ethnic people and mainly dominated by Karbi Tribe. Karbi Anglong is very rich in natural resources. This district has very low infrastructure facilities as well as low literacy rate. The literacy percentage of Karbi Anglong district is very low in Assam, although the position has been improved much after Independence. Under the Indian Constitution a provision has been made for compulsory and free education up to the age of 11 years. But we have not yet achieved this target because of so many problem of education in Karbi Anglong district. The literacy rate is just 73.52 percent which is lower than national average 74.04 percent according to 2011 census. The literacy rate in rural area is much lower than urban area. Moreover, female literacy rate is lower than male in both urban and rural area. Here the problem of education is 
somewhat different from other district of Assam, especially, because of the inconvenience in communication like transport facilities, improper administration, poor power supply, religious challenge and so on. Therefore, this paper is going to focus on the problem of education in Karbi Anglong district of Assam.

\section{Objective of The Study}

- To study the problems of education in Karbi Anglong district.

- To explore the problem faced by the school going children in the present education system.

\section{Methodology}

This research is based on Secondary sources of data and personal observation. Data are collected from books, government reports, official websites and publication of other prestigious institution. Moreover, although this research is also based on personal observation, hence it is also exploratory in nature.

\section{Result and Discussion}

How many people have access basic education irrespective of their caste, religion, race, sex etc. is one of the important in the Karbi Anglong district. In other words, how many people have been attained the basic education. The Karbi dominant district Karbi Anglong's literacy rate is 73.52 percent which is lower than national average 74.04 percent according to 2011 census. Its literacy rate was only 58.83 percent in 2001. The growth rate of 2001-2011 was the positive sign which is 14.69 percent higher than 2001. However, its literacy rate is still lagging behind to Kamrup Metro, Jorhat, Siva Sagar such are 88.71 percent, 82.15 percent and 80.41 percent respectively.

The wide differences in education attainment between male and female is also one of the discussable. The female literacy rate is much lower than male basically in rural Karbi Anglong although they are playing pivotal role in the development of the district. The female literacy rate is only 61.81 percent with compared to 80.50 percent male which is 18.69 percent lower than male literacy rate according to 2011 census in rural Karbi Anglong. On other hand, in urban area, the female literacy rate is 84.02 percent where male literacy rate is 92.64 percent. The difference between male and female literacy rate is 6.62 percent is urban area whereas it is 18.69 percent in rural Karbi Anglong according to 2011 census.

\subsection{Problem of Education}

The Karbi Anglong district is facing enormous educational problem even though various measures have been taken by the government to increase the enrolment rate and reduce the dropout rate of the children. The major challenges are as follow.

- Poor Communication Facilities: The poor communication facilities in Karbi Anglong district are one of the major problems which hinders the acceleration of education. The puka road is rarely seen in the village areas and even in town areas. The constructed puka 
roads are out of the general standard. The people cannot take the motor bike in some village areas. This inconvenient road transport facilities stands as stumbling blocks for the students and the parents. Moreover, some of the villages are still uncovered by mobile network facilities because of which are unable to take the information about the schools and college through the mobile or telephone services.

- Power Electricity: Now-a-days, power can be considered as the basic needs of the people like food and shelter. The sufficient power supply is very important for the students to study regularly as some of parents cannot afford to buy solar light and Kerosene. In, Karbi Anglong, the supply of power is very poor inspite of having Karbi Langpi Hydro Electric Power (KLHEP) Project. The supply of electricity is one hour off and one hour even in main capital Diphu.

- Insufficient Educational Institution: Government negligence to Karbi Anglong district is one of the main problems for the people of this district. The pathetic government sponsored educational institution is not sufficient according to the requirement of the students basically in the college level. The venture colleges could not provide quality education to the student because of the lack of Educational Instruments.

- Poverty: The income inequality is a big challenges in the Karbi Anglong district where the rich becomes richer and the poor becomes poor. Some poor people could not provide even the basic education to their children inspite of having: The Right of Children to Free and Compulsory Education (RTE) Act, 2009 in India.

- Improper Administration: Corruption is very high and has become a part of administration in Karbi Anglong. This rampant corruption is an immense curse for the general people and it is indirectly linked to the reduction rate of enrolment and increasing dropout rate as the construction of infrastructure like roads, buildings etc. under administration of the government are not taken up properly.

- Religious Influence: It may be reluctant to accept by the people but it is true that religion sometimes stands as a hindrance for the development of the people. The homemade liquor (Hor) which is related to tribal cultural affects the people basically in rural area. The excessive use of Hor in their marriage ceremonies, worships etc. reduces seriousness of the parents about their children which ultimately affect their children education.

- Natural Difficulties: The geographical factor has a great impact on man's life. His ways of living, food habits, profession and means of transport and communication are greatly influenced by this factor. Means of transport are inadequate and they are scattered here and there. There is no dense population in western part of Karbi Anglong because these areas are mostly covered by hills. As a result, many children in western part of Karbi Anglong cannot go to school because of unfavorable geographical localities. Teachers do not like to work in schools of difficult geographical surrounding. Hence, natural obstruction has come in the way of expansion of education in Karbi Anglong District.

\section{Conclusion}

Education is necessary not only for private individual, it is necessary for whole society development as well. Therefore, the problem which are faced by the people of Karbi Anglong are necessary to reduce by the proper administration. The district council should be funds inflows which are meant for the development of education in the district should fully utilized and spend justly. The state government should timely mobilize the funds where the district council 
can use it on time. Moreover, people political consciousness and strong pure non-political organization is necessary to tackle the corruption in the district itself.

\section{References}

[1] India. Directorate of Economics and Statistics. (2015). Statistical handbook. Retrieved from http://ecostatassam.nic.in/.

[2] Agarwalla, Dr. Sunita (2016). Educational optional for acs mains examination. Guwahati, India: Aditya Book Distributor.

[3] Chaube, Dr. S.P. (2010). Problem of Indian Education. Shri Vinod Pustak Mandir, Agra-2

[4] Shrimali, K.L.: Problems of Education in India- Publication Division Bharat Sarkar,1961

[5] Mukerji, S.N.: Higher Education and Rural Education- Barodo Acharya Book Depot, 1956, P.342.

*Corresponding author.

E-mail address: sobitatokbipi123@gmail.com 